\title{
Uji Fitokimia dan Antioksidan dari Daun Yantan (Blumea chinensis DC)
}

\author{
Griffin A.D. Rambi a*, Vanda S. Kamu a, Max R.J. Runtuwene a \\ aJurusan Kimia, FMIPA, Unsrat, Manado
}

\begin{tabular}{l}
\hline KATA KUNCI \\
\hline yantan \\
fenolik \\
flavonoid \\
antioksidan
\end{tabular}

\begin{abstract}
A B S TRAK
Telah dilakukan penelitian untuk menentukan kandungan fitokimia dan aktifitas antioksidan dari ekstrak etanol daun yantan (Blumea chinensis $D C$ ). Kandungan fitokimia yang diuji adalah total fenolik dan total flavonoid. Total fenolik menggunakan metode Folin-Ciocalteu (Yadaf dan Agarwala, 2010), lalu untuk mengetahui total flavonoid menggunakan aluminium klorida (Sultana et al., 2011), dan pengujian aktifitas antioksidan menggunakan 1,1-difenil-2-pikrilhidrazil (DPPH) (Subedi et al., 2011). Hasil penelitian menunjukan kandungan fenolik total sebesar $26,75 \mathrm{mg} / \mathrm{L}$ dan kandungan flavonoidnya sebesar $12,56 \mathrm{mg} / \mathrm{L}$,untuk pengujian aktifitas antioksidan didapatkan nilai IC 50 sebesar 240,19 $\mathrm{mg} / \mathrm{L}$.
\end{abstract}

\section{K E Y W O R D S}

yantan

phenolic

flavonoid antioxidant

\begin{abstract}
A B S T R A C T
Research have been done to determining the phytochemical compound and antioxidant activity of yantan (Blumea chinensis DC) leaves. The phytochemical compound which tested is phenolic total and flavonoid total. Phenolic total using Folin-Ciocalteu method (Yadaf dan Agarwala, 2010), then to determining the total flavonoid using aluminium chloride (Sultana et al., 2011), and test of the antioxidant activity using 1,1-difenil2-pikrilhidrazil DPPH (Subedi et al., 2011).The result of the total phenolic content was showed $26,75 \mathrm{mg} / \mathrm{L}$ and the total flavonoid content is 12,56 $\mathrm{mg} / \mathrm{L}$, for antioxidant activity test obtained the value $\mathrm{IC}_{50}$ is $240,19 \mathrm{mg} / \mathrm{L}$.
\end{abstract}

TERSEDIA ONLINE

09 Februari 2016

\begin{abstract}
1. Pendahuluan
Radikal bebas apabila berada di dalam tubuh manusia berpotensi dalam terbentuknya penyakit degeneratif seperti kanker, aterosklerosis, rematik, jantung koroner, katarak, dan penyakit saraf seperti parkinson (Silalahi, 2006).Karena hal tersebut sehingga selalu dicari senyawa antioksidan untuk menghambat dampak buruk dari senyawa radikal. Menurut Charoensin (2014), radikal bebas memulai tahap awal atau tahap inisiasi dari suatu gen untuk bersifat karsinogenik, karena itu butuh senyawa antioksidan yang memiliki aktifitas penangkal radikal bebas untuk mencegah radikal bebas berinisiasi menghasilkan zat pemicu penyakit degeneratif. Senyawa yang bisa berfungsi sebagai antioksidan adalah senyawa flavonoid dan polifenol.
\end{abstract}

Hasil penelitian sebelumnya, daun yantan mengandung senyawa flavonoid dan telah di uji nilai toksisitasnya dari ekstrak yang dimaserasi dengan tiga pelarut berbeda, hasilnya nilai LC50 sampel butanol sebesar 509,9 mg/L dengan pelarut etil asetat sebesar $276,06 \mathrm{mg} / \mathrm{L}$ dan dengan pelarut petroleum eter sebesar 549,21 mg/L (Nurrani, 2014).

Dari hasil penelitian tersebut dapat menjadi informasi awal untuk melakukan penelitian lebih lanjut lagi dengan menggunakan pelarut yang berbeda dalam proses ekstraksi, juga akan diteliti kandungan fenolik dan flavonoid secara kuantitatif dan akan diuji aktifitasnya sebagai antioksidan, karena belum ada penelitian yang mendalam dari sampel tersebut untuk dibuktikan fungsinya secara 
ilmiah sebagai tanaman obat khususnya di bidang antioksidan.

\section{Material dan Metode}

Alat yang digunakan adalah neraca analitik, aluminium foil, kertas saring Whatman No. 1, sudip, ayakan 65 mesh, pemanas, desikator, oven, mikropipet, spektrofotometer UV-Vis, evaporator, vorteks, incubator, rak tabung reaksi, blender dan beberapa alat gelas kimia lainnya.

Bahan yang digunakan dalam penelitian ini adalah daun yantan yang diperolah dari desa Lolak kabupaten Bolaang Mongondow. Bahan kimia yang digunakan dalam penelitian ini adalah etanol, natrium karbonat, aluminium klorida, asam galat, quersetin, 1,1-difenil-2-pikrilhidrazil (DPPH) dengan kualitas p.a.0.2 $\mu \mathrm{m}$, dan Whatman $0.45 \mu \mathrm{m}$.

\subsection{Preparasi Sampel}

Sampel daun yantan dicuci kemudian dikeringanginkan selama 2 minggu dalam suhu ruang. Setelah kering sampel diblender hingga berbentuk serbuk, kemudian diayak dengan ayakan 65 mesh. Selanjutnya dimasukkan kedalam oven dengan suhu $40^{\circ} \mathrm{C}$ selama tiga hari. Setelah tiga hari diuji kadar airnya.

\subsection{Uji Kadar Air}

Pengujian kadar air dilakukan mengikuti Sudarmadji (1980), yang dimodifikasi. Wadah kosong sebagai tempat untuk menguji sampel ditimbang terlebih dahulu dan dicatat sebagai W1. Lalu sampel ditimbang dengan berat sekitar $2 \mathrm{~g}$ yang dicatat sebagai W2, diletakkan ke wadah kosong yang telah ditimbang sebelumnya dan dimasukan ke oven dengan suhu $110{ }^{\circ} \mathrm{C}$ selama 3 jam. Setelah 3 jam, sampel dimasukan kedalam desikator hingga 1 jam untuk membuat berat sampel konstan. Setelah itu ditimbang berat sampel beserta wadahnya dan dicatat sebagai W3. Pengujian kadar air dapat dihitung dengan persamaan:

$$
\text { W Kadar Air }=\frac{(W 1+W 2)-W / 3}{W / 2} \times 100 \%
$$

W1 = Berat cawan kosong

W2=Berat sampel

W3=Berat cawan + sampel yang telah dipanaskan

\subsection{Ekstraksi (Yusuf et al., 2014)}

$80 \mathrm{~g}$ serbuk daun yantan direndam dengan petroleum benzena, setelah itu residunya dimaserasi dengan etanol sebanyak $160 \mathrm{~mL}$ dikocok dan didiamkan selama 24 jam. Kemudian disaring dengan kertas saring dan didapatkan filtrat yang pertama, lalu diulangi dengan penambahan etanol dengan volume yang sama hingga 3 kali setiap 24 jam sampai didapatkan 3 filtrat. Ketiga filtrat digabungkan dan dievaporasi menggunakan evaporator, hasil evapnya ditempatkan di cawan petri lalu disimpan untuk pengujian selanjutnya.

\subsection{Analisis Kandungan Fenolik (Yadaf dan Agarwala, 2011)}

Konsentrasi larutan sampel dibuat $1000 \mathrm{mg} / \mathrm{L}$. Selanjutnyadiambil 0,1 $\mathrm{mL}$ dari larutan yang dibuat sebelumnya lalu ditambahkan 0,1 mL Follin 50\% dan $2 \mathrm{~mL}$ larutan $\mathrm{Na}_{2} \mathrm{CO}_{3} 2 \%$ setelah itu dibaca pada panjang gelombang $750 \mathrm{~nm}$ dengan menggunakan spektrofotometer UV-Vis.

\subsection{Uji Kuantitatif Flavonoid (Sultana et al., 2014)}

Dibuat larutan stock sebesar $1000 \mathrm{mg} / \mathrm{L}$ dari larutan stok, kemudian diambil $1 \mathrm{~mL}$ dari 1000

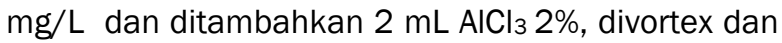
dibaca pada panjang gelombang $415 \mathrm{~nm}$ dengan menggunakan spektrofotometer UV-Vis.

\subsection{Uji Aktifitas Antioksidan (Subedi et al., 2012)}

Dibuat $100 \mu \mathrm{M}$ 1,1-difenil-2-pikrilhidrazil (DPPH) dalam etanol dan diambil $1000 \mu \mathrm{L}$ lalu dtambahkan dalam $500 \mu \mathrm{L}$ ekstrak daun yantan ke dalam tabung reaksi yang telah dibuat variasi konsentrasi sebesar 50, 100, 150, 200, dan 250 $\mathrm{mg} / \mathrm{L}$ dan diinkubasi dalam gelap selama 30 menit, setelah itu diinkubasi dalam gelap selama 30 menit dan diukur absorbansinya pada $\wedge 517 \mathrm{~nm}$ dengan menggunakan spektrofotometer UV-Vis.Untuk kontrolnya atau blanko mengandung etanol dengan DPPH tanpa dimasukan ekstrak.

Aktifitas penangkal radikal bebas $(\%)=$

$$
1-\left(\frac{A T}{A_{0}}\right) \times 100 \%
$$

Ao: Absorbansi dari larutan DPPH

AT: Nilai absorbansi sampel yang diuji

\section{Hasil dan Pembahasan}

\subsection{Uji Kadar Air}

Uji kadar air bertujuan untuk mengetahui kandungan air yang ada di dalam sampel yang diuji. Menurut Sudarmaji et al. (1989), kandungan air dalam pengujian ini diharapkan nilainya rendah. Karena apabila kandungan airnya tinggi menyebabkan peluang hidup mikroorganisme didalam sampel besar maka bisa mempengaruhi kandungan kimia yang ada didalam sampel

Tabel 1. Kadar Air Sampel Daun Yantan

\begin{tabular}{ll}
\hline Pengujian Sampel & Kadar Air (\%) \\
\hline Ulangan I & 7,98 \\
Ulangan II & 7,25 \\
\hline
\end{tabular}

Berdasarkan Tabel 1 hasil yang didapat untuk kadar air dari sampel tersebut setelah dirataratakan adalah sebesar 7,615\%. Dari hasil tersebut maka penelitian bisa dilanjutkan karena berada di bawah batas maksimum kadar air yaitu $10 \%$.

\subsection{Penentuan Kandungan Total Fenolik dan Flavonoid Ekstrak Daun Yantan}

Berikut ini adalah data kandungan total fenolik dan flavonoid dari daun yantan 


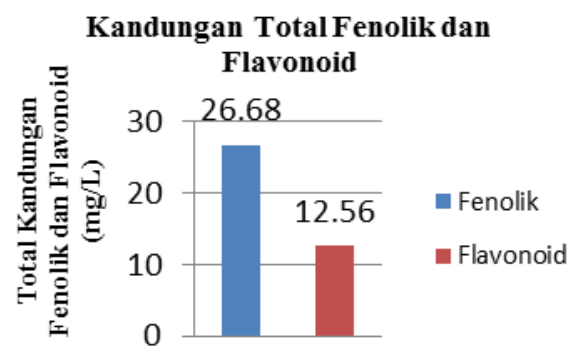

Gambar 1. Kandungan Total Fenolik dan Flavonoid Ekstrak Etanol Daun Yantan

Berdasarkan hasil dari Gambar 1 menunjukan total kandungan fenolik untuk daun yantan 26,68 $\mathrm{mg} / \mathrm{L}$ pada ekstrak etanol dengan konsentrasi 50 ppm. Reaksi sampel dengan reagen Folin terjadi dengan berubahnya warna sampel yang direaksikan menjadi warna biru yang disebabkan kemampuan sampel untuk mereduksi reagen Folin-Ciocalteu yang mengandung senyawa asam fosfomolibdatfosfotungstat, reaksi ini menghasilkan senyawa kompleks baru molybdenum tungstate berwarna biru (Ukieyanna, 2012).

Berdasarkan Gambar 1 didapat kandungan total flavonoid sebesar $12,56 \mathrm{mg} / \mathrm{L}$ dengan dua pengulangan menunjukan bahwa kandungan flavonoid lebih rendah dibandingkan dengan total kandungan fenolik pada konsentrasi 50 ppm. Data tersebut telah sesuai karena flavonoid adalah bagian dari fenolik

Menurut Sultana et al. (2014), penggunaan $\mathrm{AICl}_{3}$ pada pengukuran kadar flavonoid karena senyawa flavonoid dapat bereaksi dengan logam $\mathrm{Al}^{3+}$ pada gugus hidroksi, keton, dan orto-dihidroksi dan membentuk senyawa kompleks berwarna kuning. Makin pekat warna kuning yang dihasilkan maka konsentrasi dari flavonoid juga akan semakin tinggi.

\subsection{Penentuan Aktifitas Penangkal Radkal Bebas dengan Metode 1,1-difenil-2-pikrilhidrazil (DPPH) Ekstrak Daun Yantan}

Dalam uji penangkalan aktifitas antioksidan digunakan larutan DPPH yang bersifat sebagai radikal bebas stabil. Senyawa radikal seperti DPPH dapat secara langsung berikatan dengan antioksidan dan aktifitasnya dapat diukur pada panjang gelombang $517 \mathrm{~nm}$. Menurut Subedi et al. (2012), pengukuran pada panjang gelombang tersebut dapat menurun apabila elektron ganjil dari atom nitrogen dalam DPPH direduksi dengan penerimaan sebuah atom hidrogen dari senyawa yang bersifat antioksidan.

Berdasarkan Gambar 2, aktifitas penangkal radikal bebas paling tinggi berada pada konsentrasi 250 ppm dengan aktifitas penangkalan sebesar 52,1 \%. Menurut Molyneux (2004), DPPH ketika direaksikan dengan suatu senyawa yang dapat mendonasikan satu atom hidrogen, maka DPPH berubah menjadi bentuk tereduksi dan berubah dari warna ungu menjadi kuning yang merupakan gugus pikril. Dari persamaan linier yang didapat dari Gambar 5, nilai IC50 yang didapat sebesar 240,191 $\mathrm{mg} / \mathrm{L}$.

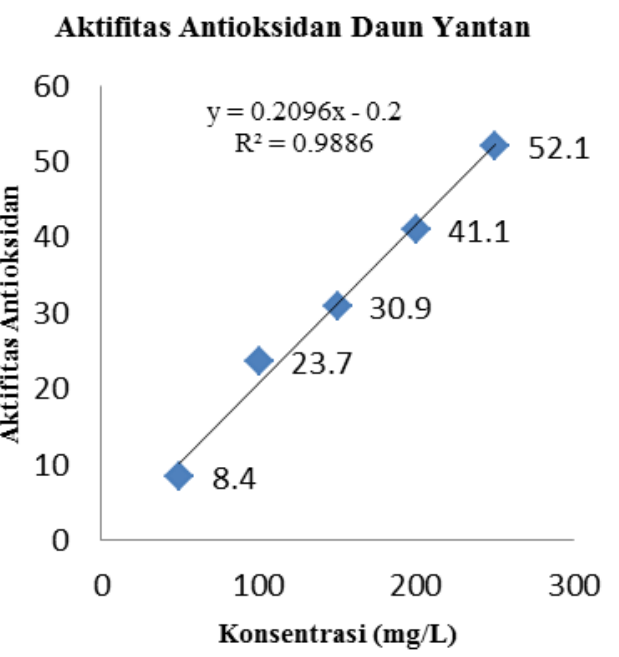

Gambar 2. Aktifitas Antioksidan

\section{Kesimpulan}

Dari hasil penelitian yang telah dilakukan, daun tanaman yantan berpotensi sebagai antioksidan, dibuktikan dengan pengujian menggunakan DPPH dan didapatkan nilai IC 50 sebesar 240,191 mg/L. Daun yantan juga memilikitotal kandungan fenolik sebesar 26,75 mg/L dan total kandungan flavonoid yaitu $12,56 \mathrm{mg} / \mathrm{L}$, kedua senyawa tersebut mendukung potensi daun yantan sebagai antioksidan.

Daftar Pustaka

Charoensin, S. 2014. Antioioksidaxidant and Anticancer Activities of Moringa oleifera Leaves. Journal of Medicinal Plant Research. 8: 318-325

Molyneux, P. 2004. The Use of The Stable Free Radical Diphenylpicrylhidrazil (DPPH) for Estimating Antioxidant Activity. Songklanakarin Journal Science Technology. 26: 211-219

Nurrani, L., J. Kinhon, dan S. Tabba. 2014. Kandungan Bahan Aktif dan Toksisitas Tumbuhan Hutan Asal Sulawesi Utara yang Berpotensi sebagai Obat. Jurnal Penelitian Hasil Hutan. 2: 123-138

Silalahi, J. 2006. Makanan Fungsional. Kanisius. Jogjakarta

Subedi, A., M.P. Aimatya, T.M. Shrestha, S.K. Mishra, and B.M. Pokhrel. 2012. Antioxidant and Antibacterial Activity of Methanolic Extract of Machilus odoratissima. Journal of Science,Engineering and Technology. 8: 73-80

Sudarmadji, S., B. Haryono., dan Suhardi. 1980. Prosedur Analisis untuk Bahan Makanan dan Pertanian. Liberty, Yogyakarta

Sultana, M., P.K. Verma., R. Raina., S. Prawez., dan M.A. Dar. 2012. Quantitative Analysis of 
TotalPhenolic, Flavonoids and Tannin Contents in Acetone and n-hexane Extract of Ageratum conyzoides. International Journal of ChemTech Research. 3: 996-999

Ukieyanna, E. 2012. Aktifitas Antioksidan, Kadar Fenolik, dan Flavonoid Total Tumbuhan Suruhan (Peperomia pelucida) [Skripsi]. FMIPA UNSRAT, Manado.
Yadav, R.N.S., dan M. Agarwala. 2011. Phytochemical Analysis of Some Medicinal Plants. Journal of Phytology. 12: 10-14

Yussuf, A.Z., A. Zakir., Z. Shenan., M. Abdullahi., dan S. A. Halima. 2014. Phytochemical Analysis of the Methanol Leaves Extract of Paullinia pinnata linn. Journal of Pharmacognosy and Phytotherapy. 2: 10-16 